\title{
DESIGN A SMALL DIGESTERS UNIT HEATED BY STORED SOLAR ENERGY TO PRODUCE BIOGAS
}

\author{
Darwesh, $\mathbf{M}^{*}$
}

\section{ABSTRACT}

The main objective of this research was to study and evaluate horizontal and vertical small size digesters heated by evacuated tube solar collector to produce biogas farm animal wastes. the digesters were evaluated under operating parameters such as three different temperature levels $\left(30,35\right.$ and $\left.40{ }^{\circ} \mathrm{C}\right)$, seven different of hydraulic of retention time (HRT) from 5 to 40 day and mixing time $5 \mathrm{~min} / \mathrm{h}$ and $15 \mathrm{~min} / 4 \mathrm{~h}$. Also comparison between the horizontal and vertical digesters as a function with find product L/day and, biogas productivity ( $m^{3}$ gas/d), and biogas energy ( $\mathrm{kWh} / \mathrm{m}^{3}$ manure $\left./ d\right)$

The results indicate the digester yield was varied in both horizontal and vertical with different heating temperature, mixing time and hydraulic retention time . the optimum condition with small vertical and horizontal types at a temperature $40{ }^{\circ} \mathrm{C}$ and (HRT) 35 day, get high final product 6.23 and $12.95 \mathrm{l} /$ day, biogas productivity 0.074 and $0.226 \mathrm{~m}^{3} \mathrm{gas} / \mathrm{m}^{3}$ manure/d, and biogas energy 0.632 and $0.634 \mathrm{kWh} / \mathrm{m}^{3}$ manure /day for vertical and horizontal, respectively.

\section{INTRODUCUTION}

B iogas as an alternative source of energy is gaining more recognition throughout several nations of the world. In Egypt, methane emissions are produced at 1.58 and 20.82 Giga-grams from cattle and buffalos, respectively, in 2012 according to (FAO, 2015). Bouallagui et al. (2003) used cow dung slurry and olive mill waste water treatment with various hydraulic retention time (HRT, days) under percentage total solid (TS,\%) 4, 6 and 8\%. The results showed that the highest conversion of waste to biogas was obtained at HRT of 20 days. As the HRT was decreased to 15 and 12 days, gradual increase for production (1/day). At HRT 20 days the productivity of biogas were 1.16, 1.63 and $2.341 /$ day under 4,6 and $8 \%$ of Ts, respectively.

\footnotetext{
* Lecturer of Agric. Eng. Dept., Fac. of Agric., Tanta Univ.
} 
For livestock manures, the treatment advantages offered by anaerobic digestion are killing pathogens (SahlstrÖm, 2003), reducing odours and lowering ammonia volatilization (Cantrell et al. 2008) and producing a substrate which has conserved its fertilizer value (Tambone et al., 2010). The metabolic activity involved in microbiological methanation is dependent on numerous factors such as substrate material, temperature, mixing and agitation total solids, volatile soiled, $\mathrm{PH}$ level, and $\mathrm{C} / \mathrm{N}$ ratio by (El-Ashmaway, 2004). Appels et al. (2008) mentioned that a neutral $\mathrm{PH}$ between 6.3 and 7.8 is acceptable for all the anaerobic microbial communities. Hilkiah et al. (2008) stated that the generation of biogas has traditionally been from feeds tocks such as "livestock farm waste (e.g. various manures, slurries and waste waters). In addition, they reported the general belief is that liquid- manure systems work best for anaerobic digestion in the production of biogas. Weiland. (2010) classified that the two types of bacteria to produce biogas upon temperature ranges. The first type is mesophilic bacteria ranged from 35 to $42{ }^{\circ} \mathrm{C}$ which suitable winter conditions. While, the second type is thermophilic bacteria ranged from 45 to $60{ }^{\circ} \mathrm{C}$ which suitable summer conditions. These conditions increased growth, productivity and activity of methane bacteria. Several anaerobic digester designs have emerged over the past century (Angenent et al. 2004). Giard, D. (2011). Presented seven types of digesters such as: covered earthen lagoon, completely mixed anaerobic reactor, fixed-film reactor, up-flow anaerobic sludge blanket reactoral, anaerobic sequencing batch reactor, multi-stage reactor, plug-flow anaerobic digester. The selection between of them dependent upon: energy required to keep the temperature of the digester, maintenance and repairs and the hiring of a part time professional operator to operate the system without biological breakdown. Yuan et al. (2011) employed the U- tube solar collector to heat the digester alternative conventional energy sources such as fossil fuels and electricity. They used solar energy as a renewable energy source and to supply the necessary energy requirements at minimum cost. The main objectives of this study were to manufacture the horizontal and vertical small size digesters, possibility of using storage energy for digesters heating by evacuated tube solar collector, maximize biogas 
production from farm animal wastes and study the effect of hydraulics retention time and temperature on biogas production.

\section{MATERIAL AND METHODS}

The experiment was carried out at the Agricultural Engineering Department of Tanta University( latitude angle of $30.5^{\circ} \mathrm{N}$, longitude of $30.6^{\circ}$ E) in Nov. 2104 to Jan 2015. Horizontal and vertical small size digesters and solar energy systems built at faculty of agriculture roof to produce biogas from farm animal wastes. The digestion system was batch anaerobic fermentation under different temperature levels; hydraulic retention times $\left(\mathrm{HRT}_{\mathrm{s}}\right)$ and two levels of agitate time.

The digesters were evaluated under operating parameters such as three different temperature levels ( 30,35 and $40{ }^{\circ} \mathrm{C}$ ), Different sensors were employed to measure temperatures connected with data logger system, The computer card are consisted of 16 channels for measuring temperature. A software program was employed to read, display, and record the data in intervals of 5 minutes. Seven different of hydraulic of retention time (HRT) and mixing time 5 and $15 \mathrm{~min} / 4 \mathrm{~h}$. to study the effect of hydraulics retention time, mixing time and temperature on biogas production addition to the possibility of using sorted solar energy systems for heating the biogas unites

Animal waste: Cattle dung were used as a source to fed the digesters obtained from the dairy farms. The chemical properties of cattle dung showing in Table 1. The total volume of diluted cattle dung fed to the biogas digester was $0.10 \mathrm{~m}^{3}$

Table(1) The chemical analysis of cattle dung

\begin{tabular}{|l|l|l|l|l|l|l|}
\hline Parameter & $\begin{array}{l}\text { Total } \\
\text { solids }\end{array}$ & $\begin{array}{l}\text { Volatile } \\
\text { solids }\end{array}$ & $\begin{array}{l}\text { Total } \\
\text { nitrogen }\end{array}$ & $\begin{array}{l}\text { Organic } \\
\text { carbon }\end{array}$ & $\begin{array}{l}\text { CW } \\
\text { ratio }\end{array}$ & PH \\
\hline Percentage & $\mathbf{1 2 . 1 0}$ & $\mathbf{7 7 . 3 0}$ & $\mathbf{1 . 1 6}$ & $\mathbf{3 6 . 1 0}$ & $\mathbf{3 1 . 4 5}$ & $\mathbf{6 . 6 - 7 . 2 5}$ \\
\hline
\end{tabular}

-Chemical analysis.

-Total solids (TS). and Volatile solids (TVS) measured according to the American Public Health Association (APHA,1989).

\section{-Organic matter and organic carbon (OM \& OC).}

The percentage of organic matter was estimated from the percentage of ash (550-600 oC), using the following equations (Black et. al., 1965):- 
Organic matter $(\%)=100(\%)-\operatorname{ash}(\%)$

Organic carbon $(\%)=$ Organic matter $(\%) / 1.8$

- Hydrogen concentration ion $(\mathrm{pH})$. The $\mathrm{pH}$ was directly measured in liquid samples using glass electrode $\mathrm{pH}$ meter.

-Bench-scale biogas digester: A bench- scale of cylindrical biogas digester (horizontal (B) and vertical (A) types) are shown in Fig. 1 Each digester was fabricated from stainless steel sheet $1.5 \mathrm{~mm}$ thickness, $80 \mathrm{~cm}$ length and $40 \mathrm{~cm}$ diameter with total capacity of 100 liters and it has a PVC inlet and outlet tube of $76.2 \mathrm{~mm}$ (3 in.) diameter for feeding by organic wastes and rejecting the digester materials. To follow up the digestion processes, orifice for releasing the produced gas was provided to the digester and another for the $\mathrm{pH}$ - temperatures measurements. Released gas volumes was collected in gasholder and determined by using the wetted displacement with a previously calibrated scale in liter.A has mixer was mounted with the biogas digester; and adjusted automatically at 5 minutes each one hour and 15 minute each four hours.

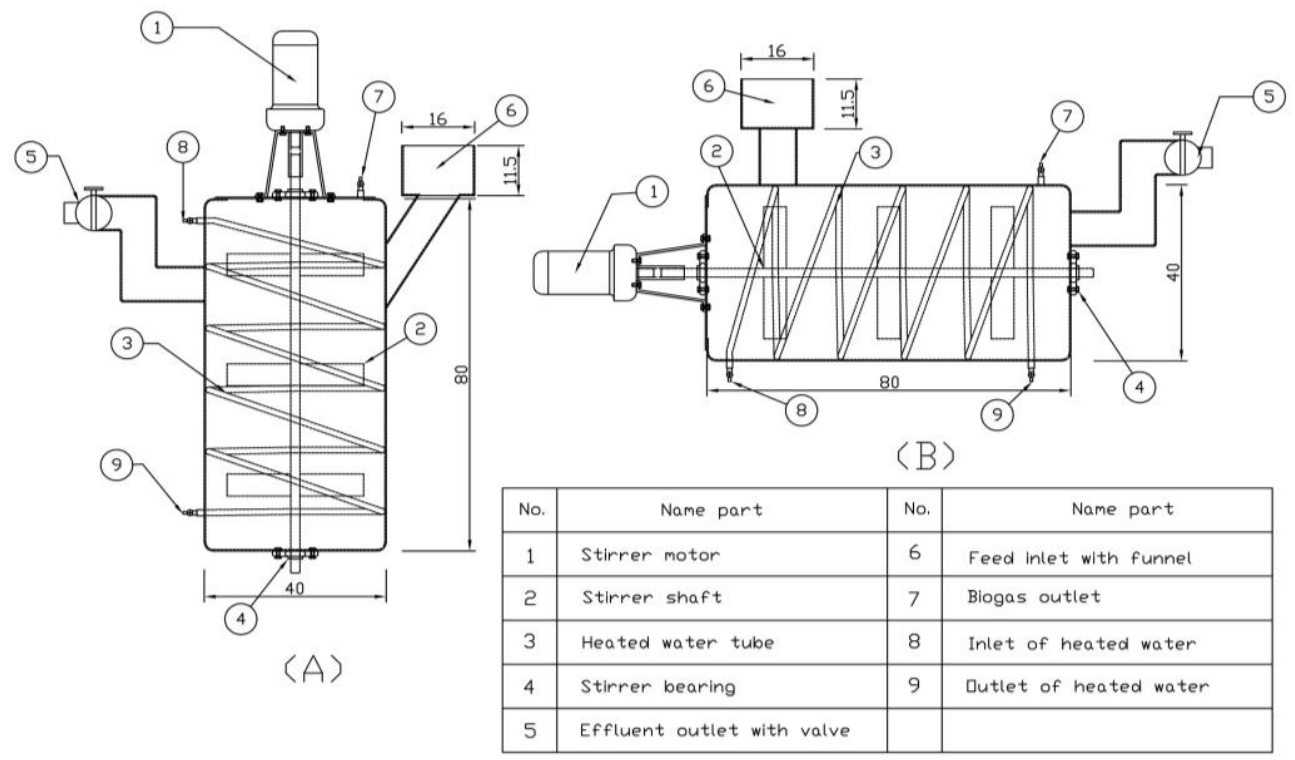

Fig. 1. The biogas digester are horizontal (B) and vertical (A) shape

\section{-Solar energy systems}

A evacuated tube solar energy systems was built with vertical and horizontal digesters. A circulation pump is used to circulate the working fluid between 
the collector and the storage tank. The solar storage tank is a 1501 insulated vessel., the pump is switched off according to the collector temperature adjustment

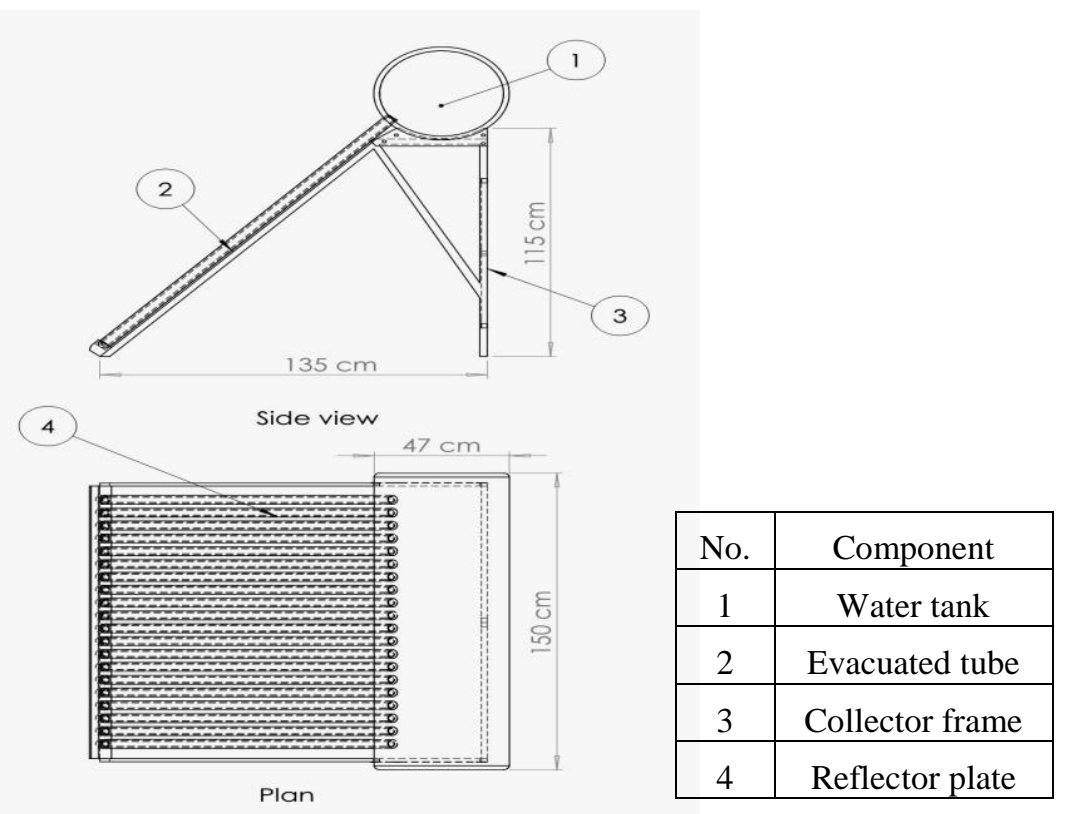

Fig. (2) Evacuated tube solar collector

\section{Instrumentation}

-Thermistores: The thermistor were used (NTC) and three are carbon resistors $500 \mathrm{Ohms}$ at $0{ }^{\circ} \mathrm{C}$

-pH meter: The liquid $\mathrm{pH}$ meter (AD-8000, Germany ( $\mathrm{pH}$ of waste) was measured the concentration of Hydrogen ion $(\mathrm{pH})$ of cattle west

\section{Measurements}

- Solar energy stored for biogas production: This a ratio between quantity of solar energy stored and quantity of biogas production can be estimated from the following equation:-

$$
\frac{Q_{s}}{q a}=\frac{M s C p\left(T_{e}-T_{b}\right)}{1000 \times q_{a}}
$$

Where: $Q_{s}$ is solar energy stored in $k W$ (Abdellatif et al., 2009), $q_{a}$ is a quantity of biogas production, $M s$ is the mass flow rate of water, $(150 l i t e r / 3600=0.04 \mathrm{~kg} / \mathrm{s}), \mathrm{Cp}$ is specific heat of water, $\left(4200 \mathrm{~J} / \mathrm{kg} /{ }^{\circ} \mathrm{C}\right)$, 
$\mathrm{T}_{\mathrm{e}}$ is mean storage tank temperature at the end of each hour, ${ }^{\circ} \mathrm{C}$ and $\mathrm{T}_{\mathrm{b}}$ is mean storage tank temperature at the beginning of each hour, ${ }^{\circ} \mathrm{C}$.

- Animal wastes: the total volume of diluted cattle dung fed to the biogas digester was $0.1 \mathrm{~m}^{3}$, with final total solid (Ts) of $12.10 \%$. The required amount of water to adjust the total solid in the biogas digester to be $8 \%$ was calculated using the following formula (LO, et. Al., 1981) :-

$$
\mathrm{Y}=\mathrm{X}\left[\mathrm{Ts}_{1}-\mathrm{Ts}_{2} / \mathrm{Ts}_{2}\right] \text {, liter }
$$

Where $\mathrm{Y}$ is dilution volume (liter), $\mathrm{X}$ is amount of raw material added $(\mathrm{kg}), \mathrm{Ts}_{1}$ is total solid of raw material (cattle dung) and $\mathrm{Ts}_{2}=$ total solid of fermentation material.

- The Hydraulic Retention Time (HRT day): is calculated using the formula of Lo, et at. (1981) as follows:

$$
H R T=\frac{V}{L R}
$$

Where LR is loading rate $\left(\mathrm{m}^{3} /\right.$ day $)$ and V is digester Volume $\left(\mathrm{m}^{3}\right)$.

-The biogas production rate: The biogas rate $\left(\mathrm{m}^{3} / \mathrm{m}^{3}\right.$ fermented /day) product from the starter a digester with a total volume of $0.10 \mathrm{~m}^{3}$, was fed by $60 \%(60 \mathrm{~kg})$ manure, $20 \%(20 \mathrm{~kg})$ water and $20 \%$ space between solution and the head of digester a $0.02 \mathrm{~m}^{3}$.

- The biogas heat energy: This indicator can be calculated from the following equation:

$$
\mathrm{E}_{\text {methane }}=\left(\mathrm{V}_{\text {biogas }} \times \mathrm{R}_{\mathrm{m}} \times \mathrm{HV} \times \eta_{\text {comp. }}\right) / 1000
$$

Where: $\mathrm{E}_{\text {methane }}$ is methan biogs heat energy in $\mathrm{kWh}, \mathrm{V}_{\text {biogas }}$ is quantity of biogas in $\mathrm{m}^{3} / \mathrm{d}, \mathrm{R}_{\mathrm{m}}$ is a concentration of methane gas in percentage of biogas, $\mathrm{HV}$ is a heating value $\left(28 \mathrm{MJ} / \mathrm{m}^{3}\right)$ and $\eta_{\text {comp. }}$ is a combustion efficiency in dimessionless.

$\mathrm{R}_{\mathrm{m}}$ depending on digester temperature according to Abdel-Hadi and Abdel-Azeem (2008) and El-Sayed et al. (2010), as shown in Table (1) follows:

Table. (1): Methane gas in percentage biogs under different temperatures

\begin{tabular}{|l|l|l|l|}
\hline Digester temperature, ${ }^{\circ} \mathrm{C}$ & $30^{\circ} \mathrm{C}$ & $35^{\circ} \mathrm{C}$ & $40^{\circ} \mathrm{C}$ \\
\hline $\mathrm{R}_{\mathrm{m}}, \%$ & 60 & 63 & 66 \\
\hline
\end{tabular}

The biogas yield was calculated as follows: The biogas yield $=$ Total biogas produced from a digester - biogas produced from the starter. 


\section{RESULTS AND DISCUTION}

The experimental work were to study the comparison between the horizontal and vertical digesters as a function with find product liter/day and, biogas productivity $\left(\mathrm{m}^{3}\right.$ gas $/ \mathrm{m}^{3}$ manure/d), biogas production rate (liter/ $\mathrm{kg}$ TS add/d) and biogas energy $\left(\mathrm{kWh} / \mathrm{m}^{3}\right.$ manure $/ \mathrm{d}$ ) and the possibility of using the stored energy from a solar panel with a heat exchanger to heat the cattle dung solution for a biogas production. In addition, to investigate the effect of booth the temperature and the hydraulic retention time on the efficiency of anaerobic fermentation. The performance of the manufacture the horizontal and vertical small size digesters at different parameters has been discussed.

\section{-Effect of hydraulics retention time, temperature and mixing time on biogas production, liter/day}

The effect of hydraulics retention time (HRT) on biogas production shown in Fig. 3. The results revealed that by increasing of hydraulics retention time from 1 to 35 day. at horizontal digester and constant mixing time of 5 minutes each one hour.
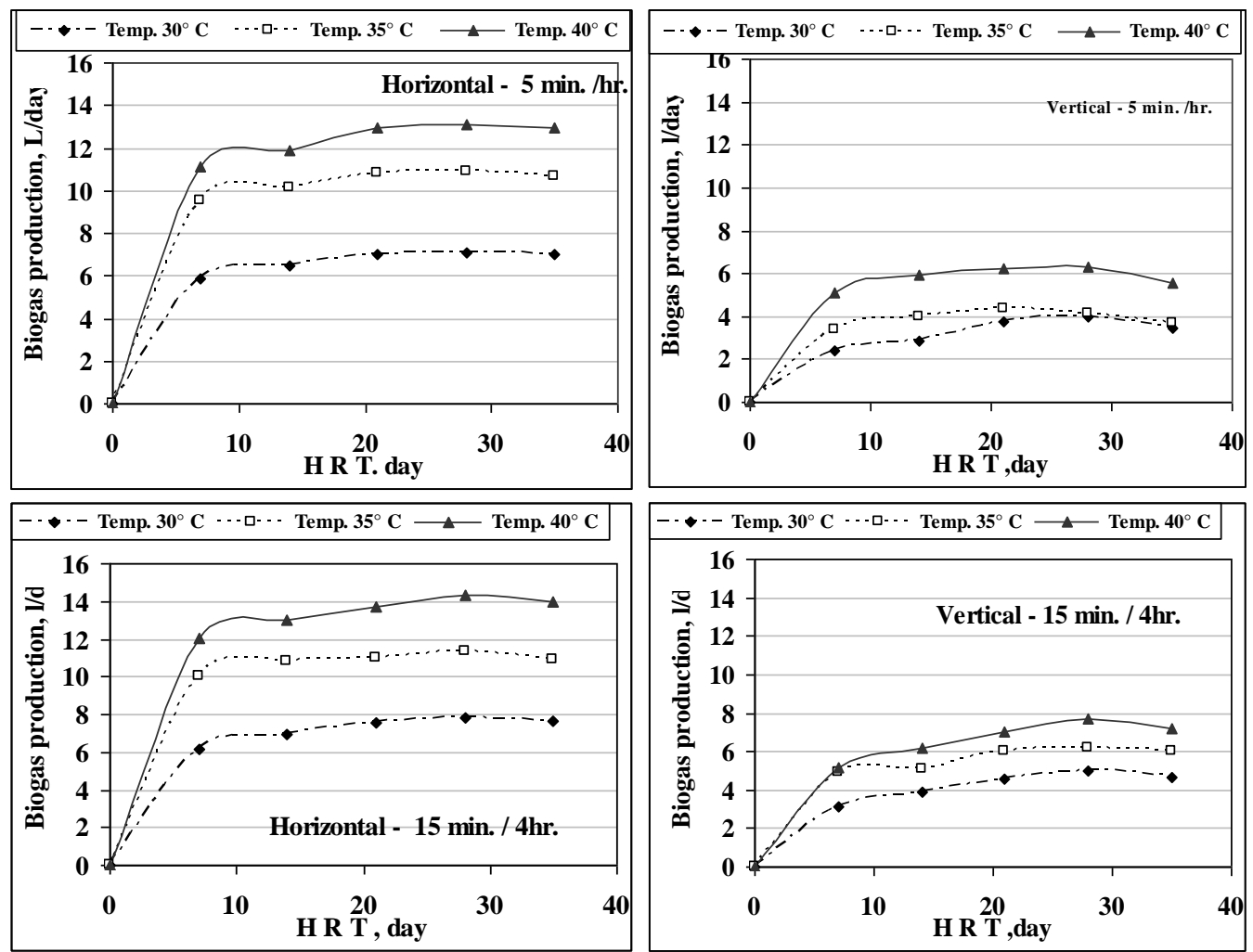

Fig. (3) : Effect of (HRT) on biogas production under different temperature and different digester type at mixing time. 
The biogas production increased from 5.83 to $7.07 \mathrm{l} /$ day, from 9.56 to $10.93 \mathrm{l} /$ day and from 11.13 to $13.13 \mathrm{l} /$ day. at $30{ }^{\circ} \mathrm{C}, 35{ }^{\circ} \mathrm{C}$ and $40{ }^{\circ} \mathrm{C}$ respectively. Also at the same conditions for vertical digester the biogas production increased from 2.39 to $3.99 \mathrm{l} /$ day, from 3.35 to $4.14 \mathrm{l} /$ day and from 5.12 to $6.31 \mathrm{l} /$ day. at $30{ }^{\circ} \mathrm{C}, 35^{\circ} \mathrm{C}$ and $40{ }^{\circ} \mathrm{C}$ respectively.

Also Fig. 3 illustrated the results indicated that by increasing of hydraulics retention time from 1 to 35 day. at horizontal digester and constant mixing time of 15 minutes each four hours. the biogas production increased from 6.14 to $7.86 \mathrm{l} /$ day, from 9.99 to $11.35 \mathrm{l}$ / day and from 12.03 to $14.32 \mathrm{l} /$ day. at $30{ }^{\circ} \mathrm{C}, 35{ }^{\circ} \mathrm{C}$ and $40{ }^{\circ} \mathrm{C}$ respectively. Also at the same conditions for vertical digester and constant mixing time of 15 minutes each four hours. the biogas production increased from 3.14 to $4.96 \mathrm{l} /$ day, from 4.92 to $6.21 \mathrm{l} /$ day and from 5.18 to $7.68 \mathrm{l} /$ day. at 30 ${ }^{\circ} \mathrm{C}, 35^{\circ} \mathrm{C}$ and $40{ }^{\circ} \mathrm{C}$ respectively..

\section{-Effect of hydraulics retention time, temperature and mixing time on total gas production, liter.}

Fig. 4 showing In horizontal digester and constant mixing time of 5 minutes each one hour the total quantity of biogas produced was 32.35, 51.10 and $61.09 \mathrm{~L}$ at $30{ }^{\circ} \mathrm{C}, 35^{\circ} \mathrm{C}$ and $40{ }^{\circ} \mathrm{C}$ respectively. While, the total quantity of biogas at constant mixing time of 15 minutes each four hours. $35.25,53.03$

and $65.96 \mathrm{~L}$ at $30{ }^{\circ} \mathrm{C}, 35{ }^{\circ} \mathrm{C}$ and $40{ }^{\circ} \mathrm{C}$ respectively. The results indicated that In vertical digester and constant mixing time of 5 minutes each one hour the total quantity of biogas produced was $15.44,18.47$ and $28.15 \mathrm{~L}$ at $30^{\circ} \mathrm{C}, 35^{\circ} \mathrm{C}$ and $40^{\circ} \mathrm{C}$ respectively. While, the total quantity of biogas at constant mixing time of 15 minutes each four hours. 20.23, 27.24 and $32.25 \mathrm{~L}$ at $30{ }^{\circ} \mathrm{C}, 35^{\circ} \mathrm{C}$ and $40{ }^{\circ} \mathrm{C}$ respectively.

\section{Effect of mixing time and temperature on biogas productivity}

The volumetric biogas productivity $\left(\mathrm{m}^{3}\right.$ gas $/ \mathrm{m}^{3}$ manure/day), is shown in Fig. 5. The daily average biogas productivity during this experiment was $0.061,0.160$, and $0.168\left(\mathrm{~m}^{3}\right.$ gas $/ \mathrm{m}^{3}$ manure/d) for the three different treatments $\left(30,35\right.$ and $\left.40^{\circ} \mathrm{C}\right)$ respectively at horizontal digester while in vertical digester the results revealed that the daily average biogas productivity during this experiment was $0.069,0.175$, and $0.188\left(\mathrm{~m}^{3}\right.$ gas $/ \mathrm{m}^{3}$ manure/d) for the three different treatments $\left(30,35\right.$ and $\left.40^{\circ} \mathrm{C}\right)$, 
respectively. The higher productivity at horizontal digester revealed that increasing of subjected surface area for diluted cattle dung and equal pressures at all digester sides tented to biogas rise easily without any resistance vice versa vertical digester.
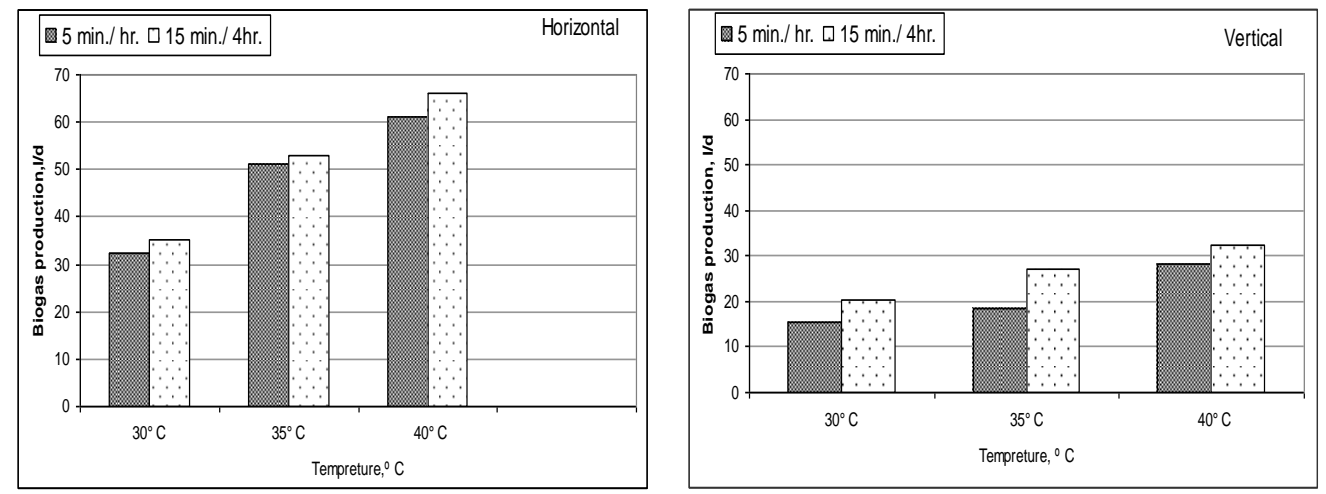

Fig. (4) : Effect of mixing time on total biogas production under different temperature and different digester type .
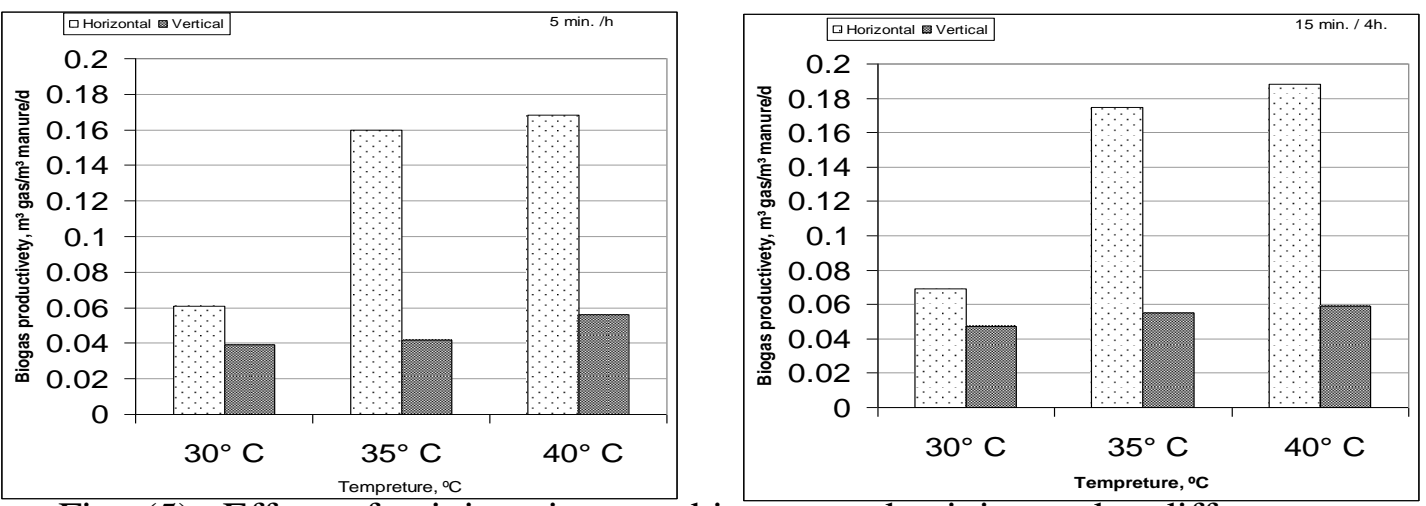

Fig. (5): Effect of mixing time on biogas productivity under different temperature and different digester types .

\section{- Effect of mixing time and temperature on $\mathrm{C} / \mathrm{N}$ ratio}

The results in Fig. 7 showed that there are differences in the declining of $\mathrm{C} / \mathrm{N}$ ratios. Generally, increasing anaerobic period resulted in a highly decreasing in $\mathrm{C} / \mathrm{N}$ ratio in all treatments of buffalo dung materials. The lowest $\mathrm{C} / \mathrm{N}$ ratio (19.46) was recorded in horizontal digester with heating of $30{ }^{\circ} \mathrm{C}$ and mixing time of $(5 \mathrm{~min} . / 1 \mathrm{~h}$.) However, the results evident that the higher $\mathrm{C} / \mathrm{N}$ ratio (32.84) was recorded in vertical digester with heating of $40{ }^{\circ} \mathrm{C}$ and mixing time of $(15 \mathrm{~min} . / 4 \mathrm{~h}$.). On the other hand, total nitrogen concentration in buffalo dung at different a anaerobic digestion was increased from zero day until end of experiment. 


\section{- Effect of mixing time and temperature on $\mathrm{pH}$ value}

The measured $\mathrm{PH}$ value for the anaerobic digester of buffalo dung in vertical and horizontal digester at experimental intervals are shown in Fig. 6. $\mathrm{pH}$ values not greatly affected by mixing in both vertical and horizontal digester. The $\mathrm{pH}$ values were ranged from 5.91 to 7.23 and 6.01 to 7.21 in horizontal and vertical digester, respectively.
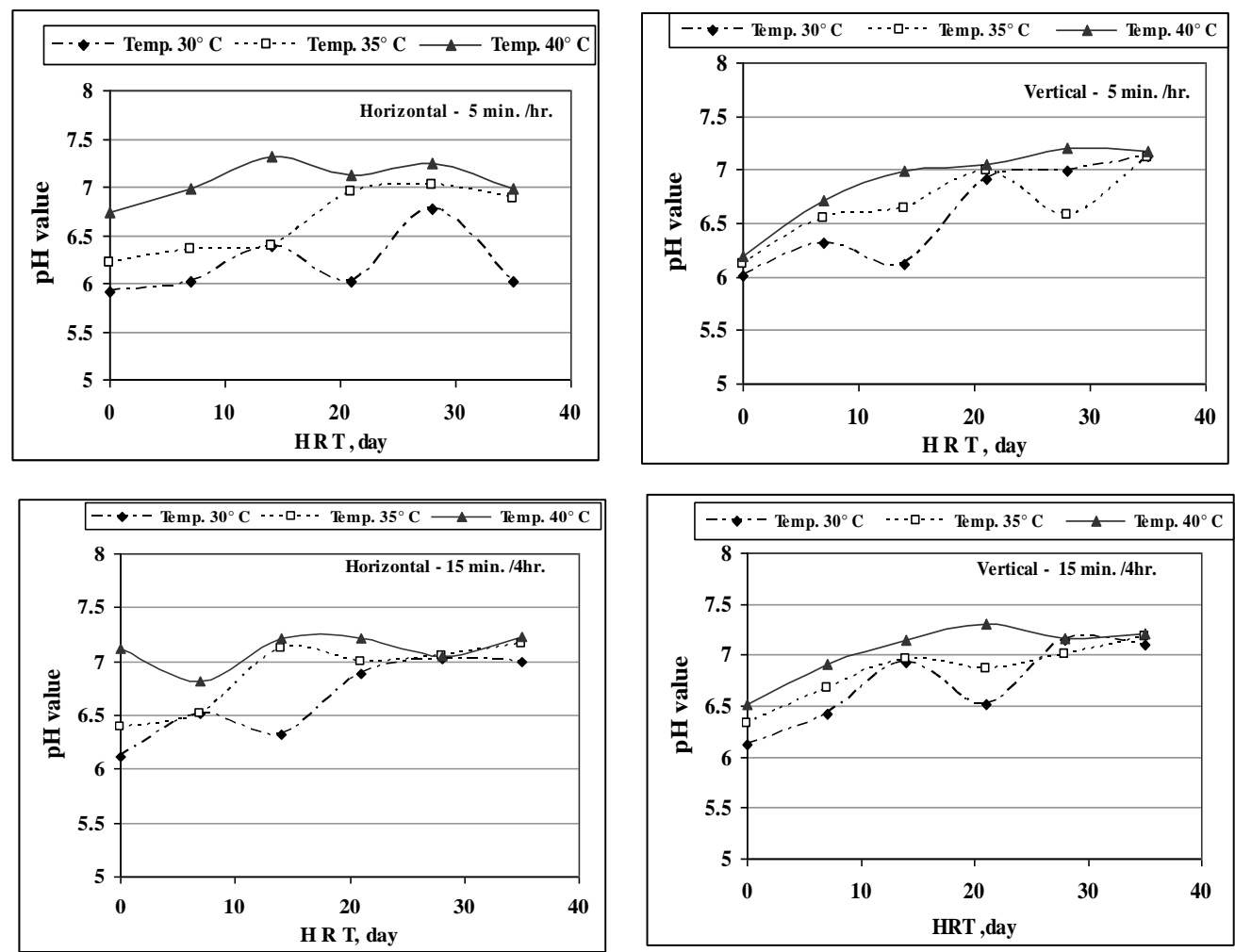

Fig.(6) Effect of (HRT), mixing time and temperature on cattle dung $\mathrm{pH}$ at vertical and horizontal digester

The $\mathrm{pH}$ is known to influence enzymatic activity, because each enzyme has maximum activity within a specific and a narrow $\mathrm{pH}$ rang. The $\mathrm{pH}$ of the digestion liquid material and its stability as well comprises an extremely important parameter, since methanogenesis only proceeds at high rate when $\mathrm{pH}$ is maintained in the neutral range. The previous result revealed that during $5 \mathrm{~min} / \mathrm{h}$ temperature of digester reach to optimum control temperature at short time this causing rise in heat which require to produce biogas. While, during operate $15 \mathrm{~min} / 4 \mathrm{~h}$ agitate time take a long time when compare it by $5 \mathrm{~min} / \mathrm{h}$ agitate time . Unfortunately, $5 \mathrm{~min} / \mathrm{h}$ 
may reduced time to reach optimum control temperature, but it produce quantity of biogas less than $15 \mathrm{~min} / 4 \mathrm{~h}$ agitate time. Because $5 \mathrm{~min} / \mathrm{h}$ agitate time process causing reduced of biogas's bacteria activity vice versa agitate $15 \mathrm{~min} / 4 \mathrm{~h}$ give biogas s bacteria a chance to activate in diluted solution.

\section{-Effect of mixing time and temperature on daily average heat energy of biogas}

In Fig. 8 the horizontal digester with agitate time of $5 \mathrm{~min} / \mathrm{h}$, the daily average heat energy of biogas was $0.108,0.178$ and $0.223(\mathrm{kWh} / / \mathrm{d})$ at $30^{\circ} \mathrm{C}, 35^{\circ} \mathrm{C}$ and $40^{\circ} \mathrm{C}$ respectively. While, the daily average heat energy of biogas with agitate time of $15 \mathrm{~min} / 4 \mathrm{~h} .0 .053,0.066$ and $0.104(\mathrm{kWh} / \mathrm{d})$ at $30^{\circ} \mathrm{C}, 35^{\circ} \mathrm{C}$ and $40^{\circ} \mathrm{C}$ respectively. However, the results indicated that in vertical digester and agitate time of $5 \mathrm{~min} / \mathrm{h}$ the daily average heat energy of biogas was $0.118,0.185$ and $0.240(\mathrm{kWh} / \mathrm{d})$ at $30^{\circ} \mathrm{C}, 35^{\circ} \mathrm{C}$ and $40^{\circ} \mathrm{C}$ respectively. While, with agitate time of $15 \mathrm{~min} / 4 \mathrm{~h}$, the daily average heat energy of biogas $0.0693,0.096$ and $0.119(\mathrm{kWh} / \mathrm{d})$ at $30^{\circ} \mathrm{C}$, $35^{\circ} \mathrm{C}$ and $40^{\circ} \mathrm{C}$, respectively.
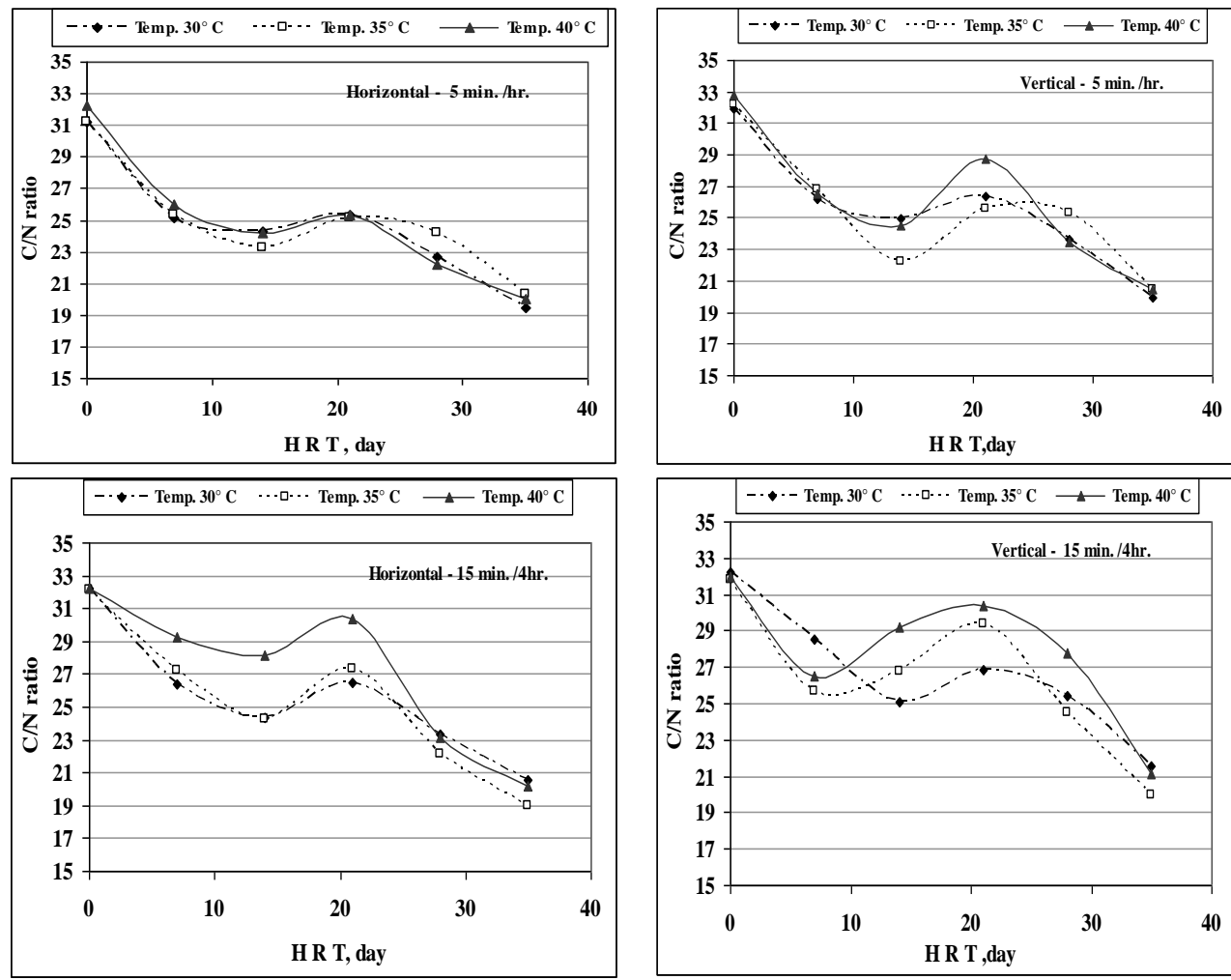

Fig. (7) Change in $\mathrm{C} / \mathrm{N}$ ratio for cattle dung during anaerobic digestion time course 

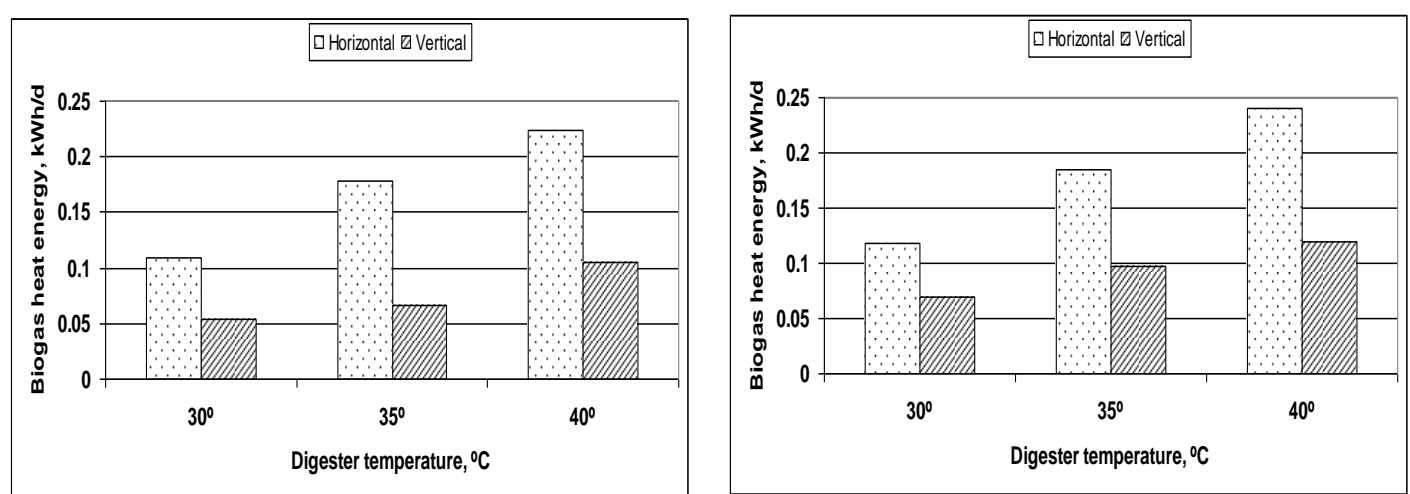

Fig.(8) : Effect of agitate time on heat energy of biogas under different temperature and different digester types .

\section{- Effect of solar energy stored on biogas production}

Fig 9. indicated that the quantity of solar energy stored which required to produce one liter of biogas per day during hydraulic retention time periods with three different levels of temperature throughout experimental research.
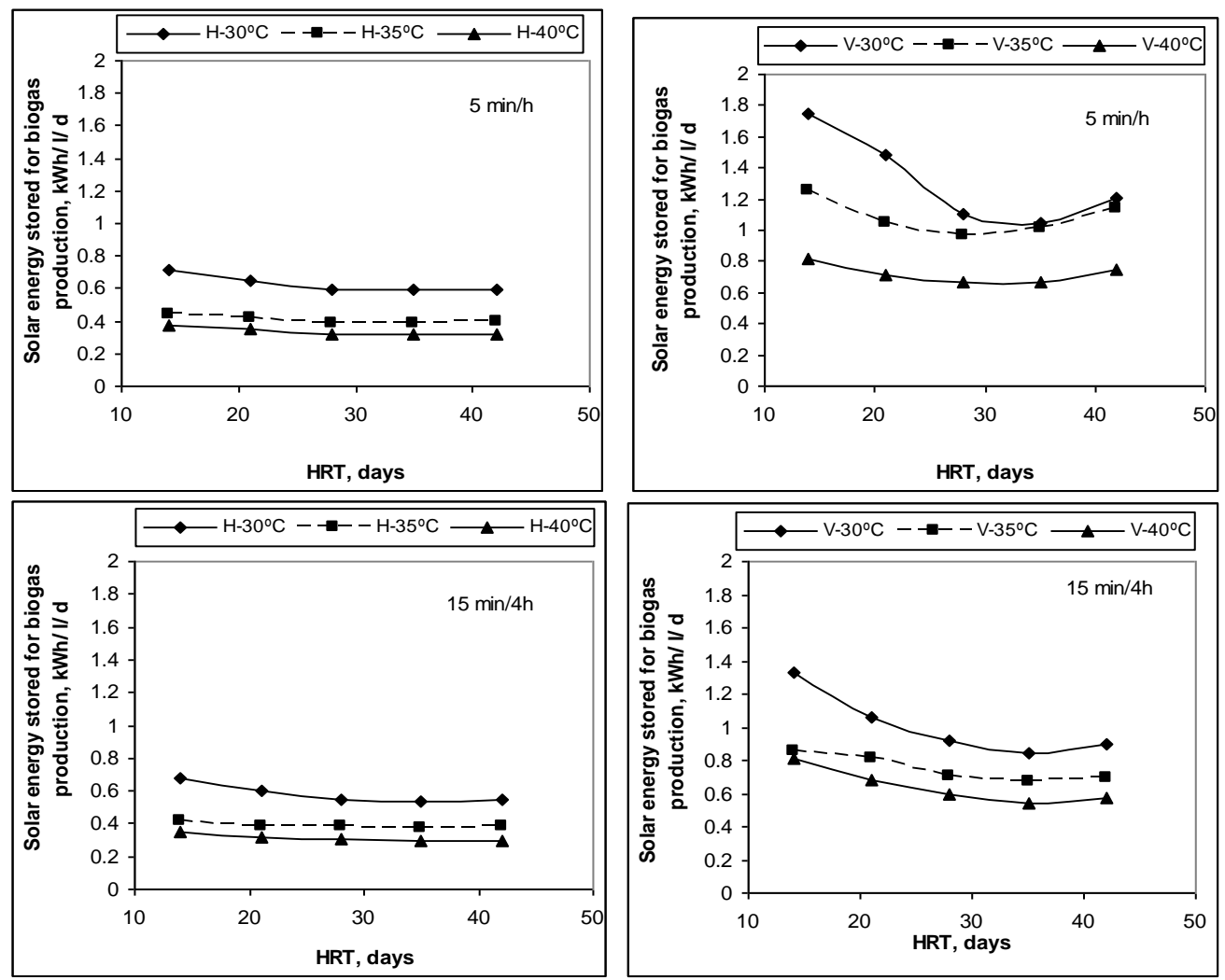

Fig.(9) : Solar energy storage requirements to produce biogas at different digester types, temperature and mixing time. 
The solar energy stored required to produce biogas is less than vertical digester because biogas quantity produced from horizontal digester is higher than vertical digester. In addition, Fig. 9 showed that higher values with $5 \mathrm{~min} / \mathrm{h}$ agitate time than $15 \mathrm{~min} / 4 \mathrm{~h}$ agitate time.

\section{CONCLUSION}

The highest biogas production was observed in horizontal digester type $12.95 \mathrm{l} / \mathrm{d}$ at agitate time of $15 \mathrm{~min} / 4 \mathrm{~h}$. and heating at $40^{\circ} \mathrm{C}$. The biogas productivity was increased by $112 \%$ in case change mixing time from $5 \mathrm{~min} . / \mathrm{hr}$. to $15 \mathrm{~min} . / 4 \mathrm{~h}$. at constant temperature $40^{\circ} \mathrm{C}$. Meanwhile, by increasing temperature from 30 to $40^{\circ} \mathrm{C}$. .069 from 0.188 increased the biogas productivity $\left(\mathrm{m}^{3}\right.$ gas $/ \mathrm{m}^{3}$ manure/day in case mixing time of 15 min. $/ 4 \mathrm{hr}$. The biogas productivity was increased by $146.81 \%$ by change digester type from vertical digester to horizontal digester in case mixing time of $15 \mathrm{~min}$. $/ 4 \mathrm{hr}$. at $30{ }^{\circ} \mathrm{C}$. The $\mathrm{pH}$ values were ranged from 5.91 to 7.23 and 6.01 to 7.21 in horizontal and vertical digester, respectively.

\section{ACKNOWLEDGEMENT}

The author is grateful to Tanta university for funding this research. This study is a part of the project entitled" Using Solar Energy to produce biogas from animal wastes and agricultural residues", project code: TU04-1304. The project started on January $1^{\text {st }}, 2013$ and will end on September $30^{\text {th }}, 2015$.

\section{REFERENCES}

Abdellatif, S. M.; N. M. Elashmay and A. M. Kassem. (2009). "Optimum tilt angle and orientation for a flat plate solar water heater under Egyptain conditions". AMA Journal, 40(3): 73-77

Abdel-Hadi, M.A. and S. A. M. Abdel El-Azeem. (2008) "Effect of heating, mixing and digester type on biogas production from buffalo dung". Misr. J. Ag. Eng, 25(4): 1454-1477

Angenent, L. T.; T. Karim.; K. Al-Dahhan.; M.H. Wrenn.; B. A. Domìuez.; R. Espinosa. (2004) "Production of bioenergy and biochmicals from industrial and agricultural wastewater". Trends in Biotechnology, 229: 477-485. 
Appels, L.; J. Baeyens.; J. Degre,ve.; K. Dewil. (2008) "Principles and potential of the anaerobic digestion of waste-activated sludge".Progress in Energy and Combustion Science, 34:755-781

Bouallagui, H.; R. BenCheikh.; L. Marouani and M. Hamdi. (2003) "Mesophilic biogas production from fruit and vegetable waste in a tubular digester". Bioresource Technology, 86: 85- 89

Cantrell, K. D.; T. Ducey.; K. S. Ro and P. G. Hunt. (2008). "Livestock waste - to- bioenergy generation opportunities". Bioresource Technology, 9917: 7941 - 7953

El-Ashmaway. (2004) "Development of solar energy systems utilizing bio-gas pilot plant". Ph. D. Thesis. Agric. Eng. Dept., Faculty of Agriculture, Mansoura University.

El-Sayed, A.S.; T. A. Mehana.; M. A. Abdel-Hadi and M. A. Mustafa. (2010) "Methane production by anaerobic digestion from cattle dung and chicken manure under laboratory conditions". The $17^{\text {th }}$ annual conference of the Misr society of Ag. Eng, 28 October: $1308-1326$

FAO, (2015) "FAO Statistics Division. Manure management". http//Faostat3, Fao.org/download/G1/Gm/E

Gird, D. (2011) "Biogas production regime for in-storage-psychrophilic anaerobic-digestion". M. SC. Thesis. Bioresource Engineering Department., Faculty of Agricultural and Environmental Sciences, Macdonald Campus of Mc Gill University, Ste-Anne-de-Bellevne, Québec, Canada.

Hilkiah Igoni, A.; M. J. Ayotamuno.; C. L. Eze.; S. O. T. Ogaji and S. D. Probert. (2008) "Designs of anaerobic digesters for producing biogas from municipal solid-waste". Applied Energy, 85: 430-438 
SahlstrÖm, L. (2003) "A review of survival of pathogenic bacteria in organic waste used in biogas plants". Bioresoure Technology, 872: 161-166

Tambone, F.; B. Scaglia.; G. D, lanporzono.; A. Schievano.; V. Orzi.; S. Salati and F. Adani. (2010) "Assessing amendment and fertilizing properties of digestates from anaerobic digestion through a comparative study with digested sludge and compost". Chemosphere, 815: 577- 583

Yuan, Su.; Rui, Tian and hong, Yang Xiao. (2011) "Research and analysis of solar heating biogas fermentation system". Procedia Environmental Sciences, 11: 1386 - 1391.

Weiland, P. (2010) "Biogas production: current state and perspective". Appl. Microbiol. Biotechnol., 85: 849 - 860.

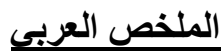

تصميم وحدة مخمرصغيرة تسخن بالطاقة الشمسية المخزنة لإنتاج الغاز الحيوي

$$
\text { د.محمد درويش }
$$

أجريت الدر اسة بالوحدة التجريبية للغاز الحيوى بقسم الهندسة الزر اعية ـ كلية الزر اعة ـ جامعة

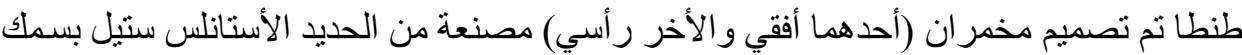

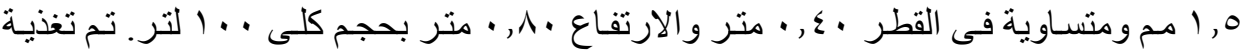

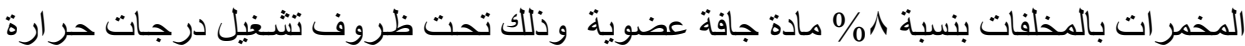

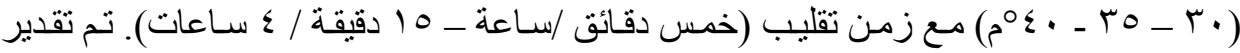

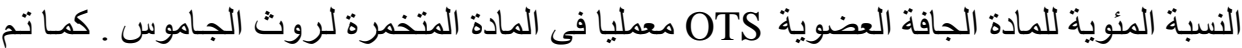

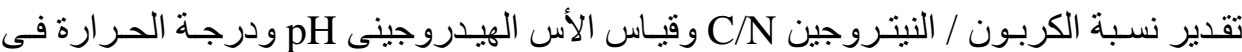

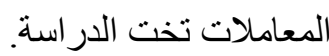

\section{وقا توصلت الادراسة إلى النتائج الآتية:}

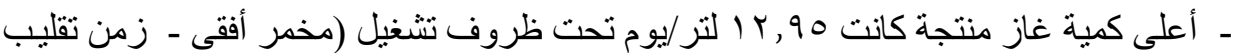

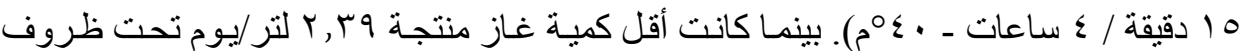

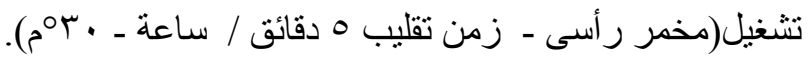

* مدرس ـ قسم الهندسة الزراعية ـكلية الزراعة - جامعة طنطا 


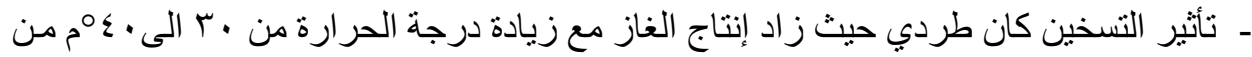

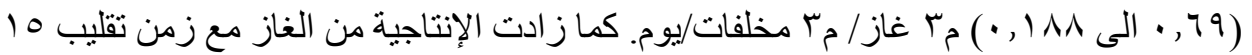

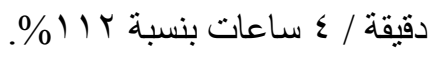

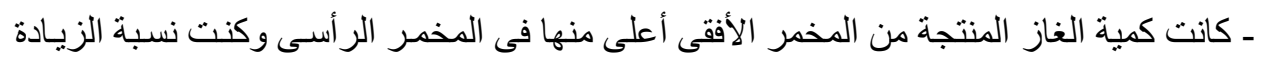

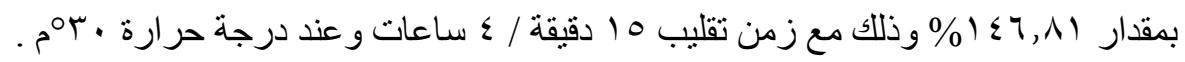

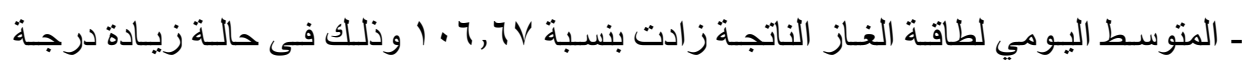

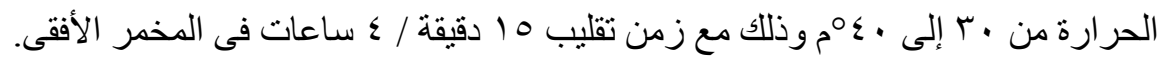

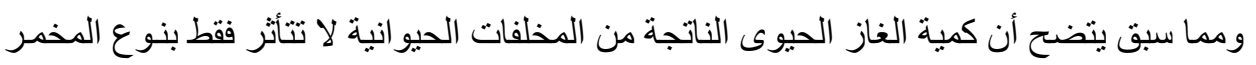

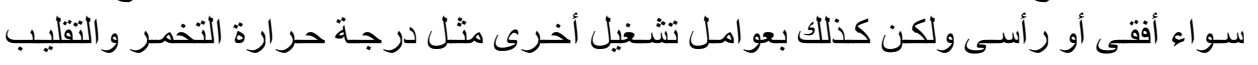

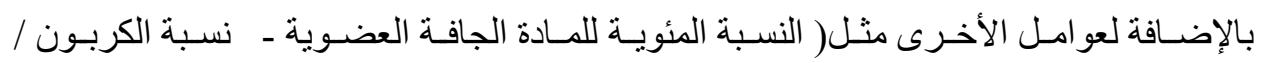
النيتروجين C/N ـ الأس الهيدروجينى pH للمادة المتخمرة.) 